\title{
Participação e projetos políticos: os horizontes da democracia brasileira - Entrevista com Evelina Dagnino ${ }^{1}$
}

Ana Claudia Teixeira ${ }^{2}$

Thiago Aparecido Trindade

Evelina Dagnino é professora da Universidade Estadual de Campinas (Unicamp), instituição a qual se encontra vinculada desde a década de 1970. No decorrer de sua carreira, coordenou e orientou projetos de pesquisas sobre movimentos sociais, cidadania, democracia, democratização, participação, sociedade civil e a relação entre cultura e política, contribuindo de forma ímpar para o debate teórico sobre democracia e participação na América Latina. Também ministrou cursos na Universidade da Costa Rica, na FLACSO e no IDES/UNGS (ambos em Buenos Aires), e nas Universidades de Yale (EUA) e Gothenburg (Suécia). Publicou livros e artigos em cerca de 20 países, o que demonstra

1 As perguntas foram elaboradas e enviadas com antecedência. A entrevista foi realizada presencialmente na cidade de Campinas (dia 6 de fevereiro de 2018), gravada, transcrita e editada. A entrevistada reviu e autorizou sua publicação. A transcrição foi realizada por Fernanda Polidoro, graduanda em Ciências Sociais pelo IFCH/Unicamp e integrante do Núcleo de Pesquisa em Participação, Movimentos Sociais e Ação Coletiva (NEPAC) da Unicamp.

2 Professora permanente do Programa de Pós-Graduação em Ciência Política da Unicamp e Pós-doutoranda (bolsista Capes) no mesmo programa. Cocoordenadora do Núcleo de Pesquisa em Participação, Movimentos Sociais e Ação Coletiva (NEPAC) da Unicamp. E-mail: anatex99@uol.com.br

${ }^{3}$ Professor adjunto do IPOL/UnB, membro do Grupo de Pesquisa sobre Democracia e Desigualdades (Demodê). E-mail: th.trindade83@gmail.com 
o alcance de suas teses e formulações teóricas ao redor do globo. Foi integrante do Board of United Nations Research Institute for Social Development (UNRISD), Genebra (2011-2016). No Institute of Development Sudies (IDS) da Universidade de Sussex (UK), atua como membro do Programme Advisory and Review Committee (PARC), para um mandato de 2017 a 2019, e membro do Advisory Group do Projeto Action for Empowerment E Accountability Programme (A4EA), 2016-2019. É Co-chair do Nominations Committee da Latin American Studies Association (LASA), 2018-2019.

Uma das principais contribuições da discussão proposta por Dagnino consiste na sua visão ampliada de democracia e de cidadania, dois processos profundamente entrelaçados que jamais puderam ser satisfatoriamente compreendidos a partir da visão mais tradicional da ciência política. Destaca-se também sua contribuição ao pensar no que ela denominou de "confluência perversa" dos projetos políticos em disputa: de um lado, o neoliberal, e de outro, o democrático-participativo, leitura que influenciou profundamente a agenda de pesquisa sobre a luta pela construção da democracia no Brasil e em diversos países da América Latina. Dentre suas produções mais citadas estão Cultures of Politics/politics of Culture, lançado em 1998 em parceria com Sonia Alvarez e Arturo Escobar, e Sociedade Civil e Espaços Públicos no Brasil, publicado pela Paz e Terra em 2002. Na condição de uma intelectual que sempre se manteve conectada aos debates políticos concretos, Dagnino optou por apostar na agência, isto é, no potencial transformador da ação humana, sem jamais ignorar os constrangimentos estruturais que condicionam essa ação.

Em nome do corpo editorial da Idéias, agradecemos imensamente à professora Evelina Dagnino por ter nos concedido esta entrevista, parte integrante do dossiê Participação política e movimentos sociais no Brasil contemporâneo, publicado nesta edição. Durante a conversa, foram abordados pontos relacionados tanto aos escritos passados da autora - o que mudou desde então no cenário político, o sentido das apostas nos espaços participativos que emergiram sobretudo a partir da década de 1990, as eventuais lacunas da análise feita naquele contexto - como também em 
relação ao momento político atual da democracia brasileira e as perspectivas mais gerais no quadro da mobilização social. Por estas razões, a presente entrevista se constitui em leitura indispensável não apenas para (as)os estudiosas(os) da área de participação e movimentos sociais, mas para todas(os) que almejam compreender melhor e qualificar sua análise sobre a nossa turbulenta conjuntura política.

Ana Claudia: Em 1998/1999 foi lançado na Revista Ideias o Dossiê de autoria do Grupo de Estudos sobre a Construção Democrática, da Unicamp. Como foi a experiência de escrita do dossiê? Na sua visão, qual a importância do grupo naquele momento?

Evelina Dagnino: Antes de falar do dossiê, eu gostaria de fazer duas observações preliminares, mais gerais, que eu acho que se relacionam com várias das perguntas. E sobre o que acho que caracteriza a dinâmica da produção de conhecimento, que talvez ajude a entender melhor as "lacunas" e os focos, as ênfases que se sucedem nas análises da ciência social. A primeira é lembrar um pouco o que normalmente se dá quando se escolhe um tema de pesquisa: focamos naquilo que achamos que não está sendo considerado de forma suficiente ou adequada, uma reflexão que está faltando, um problema pouco explorado. E aí, no processo, seguramente algo vai ficar de fora, a descoberto: as lacunas. No momento seguinte, as lacunas vão se tornar, por sua vez, novos focos de pesquisa e análise. Em aula, eu costumava, modestamente, comparar essa dinâmica à de um pêndulo, que se move entre dois pontos. Mas, se quisermos uma maneira mais sofisticada, a gente pode dizer que é o movimento dialético do pensamento social. Quer dizer, tem tese, tem antítese e espera-se a síntese, em nível mais alto da espiral. Agora, a síntese, com S maiúsculo, é para as grandes cabeças, e olhe lá.... Que autor conseguiu elaborar um pensamento que constituiu uma boa e ampla síntese dessas várias posições do pêndulo? Marx? Não creio. Gramsci? Tampouco, apesar das pontas soltas que ele conseguiu articular. 
A outra observação, que se articula com a primeira, tem a ver com algo que é muito característico, embora não exclusivo, de um pensamento social brasileiro e latino-americano. $\mathrm{O}$ fato de que esse pensamento se constrói com uma contiguidade do debate político. Ou seja, a Ciência Social se debruça sobre aquilo que está sendo discutido no âmbito da política e guiada por ela. As minhas reflexões foram profundamente guiadas por ela. Eu estou interessada naquilo que a sociedade está interessada, que o debate político está interessado. É aí que eu vou depositar as minhas energias intelectuais. Se você compara esse tipo de "engajamento"digamos assim entre aspas - com a Ciência Social americana, saxônica, europeia, você vê claramente essa diferença. É claro que essas escolhas não podem ser generalizadas, mas eu acho que há uma diferença visível na maneira como se escolhem os temas de pesquisa no Brasil e nos países latino-americanos e nos países do primeiro mundo. E é claro também que isso está relacionado com o maior ou menor grau de "colonização" da ciência social nativa...

Sobre o dossiê, eu acho que o processo de elaboração dele foi absolutamente maravilhoso. Foi um processo inovador para o momento em que ele foi realizado. Inovador por ser um processo bastante igualitário de escrita coletiva entre os participantes e que envolveu uma dose de energia, dedicação das pessoas e de entusiasmo, que não era comum naquele momento. E isso deixou frutos. $\mathrm{O}$ fato é que grande parte das pessoas que participaram do dossiê e do Grupo de Estudos da Construção Democrática continuaram investindo nesse caráter coletivo. Não coletivo no sentido mais forte do dossiê, que foi escrito em conjunto, mas no caráter coletivo de agrupar pessoas, de cultivar grupos, de cultivar debates. Isso era muito inovador no interior da universidade naquele momento e talvez continue sendo até hoje, mas muito menos, felizmente.

Tenho visto nas universidades na Europa, na Inglaterra nos Estados Unidos e mesmo no Brasil, o sofrimento dos pósgraduados. É uma realidade muito massacrante, que vejo nos orientandos que eu ainda recebo. Essa experiência do dossiê enfrentou o isolamento no trabalho intelectual. Acho, talvez, que 
não é por acaso que as relações intelectuais que se estabeleceram no GECD permanecem até hoje, até porque eram permeadas por relações afetivas muito fortes.

Em termos de conteúdo, o dossiê está marcado pela contiguidade que mencionei no início. Fomos olhar aquilo que estava no debate. A gente conseguiu juntar um conjunto de questões que não estavam necessariamente na pauta dominante. E aqui estou falando da Ciência Social brasileira. Eu não estou falando da ideologia dominante na sociedade (risos).

O domínio institucionalista na Ciência Política era muito forte naquele momento. Toda a ideia da teoria da transição, da consolidação etc. estava marcada por este domínio. A gente tentou abrir espaço. $\mathrm{O}$ dossiê trouxe à tona uma temática que não era convencional, que não fazia parte do cardápio da ciência política. Por outro lado, a nossa discussão certamente foi marcada por uma euforia muito grande. Com a construção democrática, com os movimentos sociais, com os espaços públicos. E aí a gente não estava sozinha. Era uma dose de esperança absolutamente gigantesca. Tinha uma aposta ali. Mas acho que esta aposta, no nosso caso, sempre foi combinada com o olhar crítico. Ela não era uma euforia puramente celebratória.

Para compreender o momento, é preciso dizer que todos os termos utilizados no dossiê- sociedade civil, cidadania, participação - estavam sendo ressignificados. É muito difícil imaginar nos dias de hoje como era naquela época. Havia uma disputa com o projeto neoliberal, mas também com um um certo tipo de marxismo, para o qual o que estudávamos era marginal, secundário.

AC: Uma das contribuições do seu trabalho intelectual foi sua reflexão sobre a construção democrática, na chave da relação entre cultura e política, com uma visão particular sobre o pensamento de Gramsci. Contra uma leitura de parte da literatura marxista, que tendia para um determinismo econômico nas análises dos conflitos sociais, e uma leitura da política muito voltada às institucionalidades e ao sistema político, seu enfoque foi na construção da cidadania pelos movimentos sociais e nas suas relações com o Estado. Muitos autores e alunos seus se inspiraram 
nesta perspectiva e procuraram seguir esta pista. No seu modo de ver, quais são os ganhos possíveis de serem percebidos ao analisar os trabalhos influenciados por esta perspectiva? O que foi possível apreender do real? Qual você avalia que foi o ganho central para o debate teórico sobre a democracia no Brasil?

Por outro lado, no seu modo de ver, houve limites desta abordagem? Quais questões relevantes ficaram de fora ao não se aprofundar o papel da economia e do conjunto das instituições democráticas?

ED: Nunca tive vontade de investir no terreno da Economia. Meu negócio sempre foi outro. Desde "pequenininha" (risos). Eu fiz uma tese de mestrado sobre a relação entre valores e sistema político. Depois, a primeira coisa que publiquei na vida foi um artigo sobre dependência cultural. Minha tese de doutorado é sobre a produção ideológica do Estado nos anos 30 e 40. Ou seja, desde "pequena" eu estou nessa história.

Mesmo se eu tivesse me sentido atraída por aquele terreno, alguma coisa ia ficar de fora. Eu jamais poderia ter feito "a" síntese. Eu jamais poderia ter feito tudo, digamos assim. E esse é um ponto que eu acho que está obscurecido nessas perguntas. Por isso eu quis fazer aquela primeira observação. Porque se você pergunta "quais questões relevantes ficaram de fora?", tem uma crítica aí de que a síntese não foi feita, de que a gente ocupou só um extremo do pêndulo. Acho que é fundamental identificar as lacunas, os vazios, porque apontam caminhos a seguir. Mas é importante, eu acho, reconhecer a dinâmica que as explica.

Thiago Trindade: Não acho que você deixou de fora a economia. Não era a prioridade analítica naquele momento, mas quando você fala de neoliberalismo e mercado... Bom, isso aí é economia.

ED: Ah, mas espera aí! Nós estamos falando de análise para valer. Eu não estou falando de uma referência contextual. O que eu faço é mais uma referência contextual. 
Sobre os ganhos, eu acho que a gente tentou iluminar a complexidade do processo de construção democrática. O uso dessa expressão, ao invés de falar simplesmente sobre democracia, não é só um uso decorativo. Tem várias implicações. Essa ideia da construção da democracia a gente cultivou muito. Ela é parte da disputa. A democracia não é um regime político stricto sensu, é muito mais que isso. E aí eu acho que estavam se interpelando interlocutores identificáveis. A "construção democrática" contém também a ideia de processo gradual. E isso vem direto do Gramsci. Contém também a ideia do sujeito e da agência. No sentido de que, se é uma construção histórica, necessariamente, ela requer sujeitos. Isso se conecta com todo o debate sobre os movimentos sociais, sociedade civil e etc. Tratava-se também de afirmar o estatuto dos movimentos sociais como sujeitos legítimos e relevantes, num contexto onde parte da literatura ainda afirmava o contrário, privilegiando os partidos, e outra parte, a classe operária, no sentido estrito.

Numa concepção mais estreita, os sujeitos da democratização são quem? Os partidos. Quando perguntamos naquela pesquisa " 0 que é preciso para ter democracia?", que lugar tinham os partidos na cabeça das pessoas quando se fala em democracia? Um lugar secundário, e a história depois demonstrou isso. Ao responderem esta pergunta, os entrevistados consideraram, entre as opções mencionadas, que o mais importante na democracia era que pobres e ricos, brancos e negros, homens e mulheres recebessem um tratamento igual.

Outro ganho é que na concepção de democracia falamos da natureza da relação Estado e sociedade. Isso foi elaborado teoricamente e explorado empiricamente. Aqui, de novo, há a contiguidade, porque essa relação Estado e sociedade estava sendo posta em xeque na realidade, entre outros motivos, pela "participação".

\footnotetext{
${ }^{4}$ Publicada em DAGNINO, E., FERLIM, U., SILVA, D.R., TEIXEIRA, A. C. C. Cultura democrática e cidadania. Opinião Pública, Campinas, vol. V, n⿳o 1 , novembro, 1998, p. 20-71.
} 
E, por fim, um último ganho é a ênfase na chamada "construção da hegemonia". E me refiro aqui à questão das relações entre cultura e política, uma ênfase que começamos a explorar com o livro com a Sonia Alvarez e o Arturo Escobar em 1998 (e antes disso, com a falecida área de Cultura e Política no Doutorado em Ciências Sociais no IFCH). O sucesso absurdo daquele livro (!) até hoje, 20 anos depois, acho que mostra que havia uma "lacuna" grande sobre o tema e a nossa tentativa de "síntese" até que funcionou direitinho!

AC: Quando eu perguntei o que ficou de fora ao não se olhar o conjunto das instituições democráticas estava me referindo à relação das instituições participativas com partidos, Congresso Nacional etc. Me parece que isso ficou em segundo plano e teria sido bem importante para entender as instituições participativas...

ED: Está correto. Agora que as razões para as "ênfases" estão mais claras, acho que dá talvez para entender melhor porque partidos e Congressos ficaram de fora? Já havia outros estudiosos fazendo isso, e bastante. Claro que com outra perspectiva. A "perspectiva da construção democrática" não deu conta dos partidos, embora sempre houvesse a consciência da importância da relação entre os partidos e os movimentos sociais. Eu acho que a tese da Kellen Gutierres ${ }^{5}$ é um bom exemplo de "bom, finalmente se enfrentou essa questão". E cada vez mais se enfrenta. $O$ pêndulo se moveu um pouquinho, mas tem que entender o contexto da produção intelectual. Como eu sempre dizia em aula, qualquer texto que você lê, tem que fazer essa pergunta. Qual é o contexto em que esse texto foi produzido e o que isso implica, quais são os interlocutores com quem (ou contra quem) se está debatendo?

TT: Quando você fala do pêndulo... seria correto a gente pensar que talvez exista uma certa divisão do trabalho no âmbito analítico? Enquanto alguns estão mais preocupados em olhar, por

\footnotetext{
${ }^{5}$ GUTIERRES, K. Projetos políticos, trajetórias e estratégias: a política de assistência social entre o partido e o Estado. Tese de Doutorado em Ciências Sociais. Campinas, Unicamp, 2015.
} 
exemplo, para a questão econômica e para a questão das instituições políticas no seu conjunto, vocês eram um grupo de pessoas que estavam preocupadas em olhar para a relação entre cultura e política e talvez para as questões mais vinculadas às instituições participativas. Mas para mim, faltou debater um pouco melhor a questão da dominação, do ponto de vista das questões de classe. Eu não estou falando de fazer uma análise macroeconômica, mas sim do debate sobre os conflitos materiais. Temos o orçamento participativo, mas as pessoas não estão discutindo o orçamento, os problemas orçamentários que afligem os municípios. Para onde vai essa renda? Por que o orçamento participativo tem essa limitação? O que os conselhos de políticas públicas podem fazer diante de um contexto de crise econômica? A gente está preocupado em discutir as relações ali no conselho, mas qual é o poder efetivo dessas instituições participativas diante desse cenário?

ED: Na verdade, o que eu acho que fazia falta era a questão do capitalismo, como ele funciona. Eu acho que a gente acabou substituindo o capitalismo pelo neoliberalismo. E isso facilitou as coisas, porque já não precisava mais explicar o neoliberalismo. Eu acho que o macro, o grande contexto, que é o capitalismo, como ele funciona, como ele se relaciona com essas questões todas, certamente ficou obscurecido.

Tinha uma tendência também que, certamente foi a minha desde sempre - por isso a situação atual da política nacional me afeta dessa maneira gigantesca - de pensar em coisas positivas. A aposta no futuro. "Olha, tem um projeto aí". E aí, nesse sentido, se confrontar com a dureza do capitalismo não dava!

TT: Uma das características principais da sua abordagem é a centralidade do conflito. Entretanto, curiosamente a maioria dos estudos nessa linha, inclusive a sua própria construção analítica, permaneceu focada nos espaços participativos institucionais e falou pouco sobre as ações de protesto de caráter disruptivo (o que parece ter sido uma característica do debate sobre participação no Brasil em geral). Você concorda com essa leitura? Se sim, entende que essa foi uma lacuna importante na discussão? Por quais motivos 
as ações de caráter mais conflitivas ficaram secundarizadas nesse debate? ${ }^{6}$

ED: Quando você diz que os espaços institucionalizados não são conflitivos, eu acho que aí tem um equívoco. Talvez você esteja reduzindo o conflito à disrupção -(seja lá o que for que você entende sobre isso; o dicionário diz que é "o ato de romper, ruptura, fratura"- , talvez esteja pensando no confronto que inclui elementos de violência?

Quando a gente falava de espaço público - e foi aí que o divisor de águas com o Habermas se estabeleceu com clareza - a ênfase sempre foi na ideia de que os espaços públicos são bons porque - isso está lá no dossiê com todas as letras - eles visibilizam o conflito. Eles conferem um espaço ao conflito em vez de alijarem esse conflito para outros lugares, não públicos. Primeiro, nessa pergunta, eu acho que tem uma redução da natureza do conflito. E, segundo, uma minimização do conflito no espaço institucionalizado.

Empiricamente, a realidade mostrou que, realmente, o conflito nesses espaços foi extremamente minimizado, mas a pretensão, o que se esperava, não era isso. E aí a gente pode pensar porque isso aconteceu. Não precisa ir muito longe, na verdade. Eu acho que o que a gente avaliou mal, minimizou, obscureceu, foi o tamanho da tarefa dos espaços de participação institucionalizados, o tamanho do desafio.

TT: Ou seja, a gente cobrou demais deles. É isso que você quer dizer?

ED: Não. A gente idealizou as suas possibilidades. O buraco era mais embaixo, alguém diria. Nesse sentido, eu diria que isso está no bojo da derrota. E eu estou chamando de derrota o que se passa hoje. Não é a única variável, certo? Mas certamente compõe esse conjunto de coisas que podem talvez chegar a explicar o que

\footnotetext{
${ }^{6}$ TRINDADE, T. A. Protesto e Democracia: Ocupações Urbanas e Luta pelo Direito à Cidade. Jundiaí: Paco Editorial, 2017.
} 
aconteceu. Eu acho que pensamos que o caminho seria mais fácil, que haveria um avanço, lento, mas um avanço. E não foi o que ocorreu.

TT: Será que isso não poderia, de certa forma, voltar para o ponto que a Ana Cláudia tinha destacado anteriormente, de que faltou talvez olhar um pouco mais para o conjunto das instituições? Ou seja, tentar entender os espaços participativos dentro de um contexto muito mais amplo e complexo que é essa coisa chamada "Estado".

ED: E capitalismo também. Com certeza. Agora, nossa maneira de contribuir era apostar no que estava aparecendo de novo e o que estava aparecendo de novo era, sim, a participação institucionalizada. Era "a" grande novidade! Aliás, voltando, naquele período e na questão anterior, o que havia de práticas de ação direta nos anos 1990 na sociedade?

Sobre o conjunto das instituições do Estado, com certeza, o foco foi o Executivo, nos seus vários níveis. A importância do Legislativo, por exemplo, foi marginalizada e, de novo, a história mostrou a sua (no caso, infeliz) centralidade. Nos últimos anos, tenho dito que, ao invés da democracia participativa, devíamos estudar a representativa... Com a vantagem de poder, agora, partir de outra perspectiva. Brasil.

TT: Acho que alguns movimentos sem teto espalhados pelo

AC: MST também estava lá.

TT: Eu acho que a diferença em relação ao contexto da década de 80 é que não tinham as mobilizações de massa nas ruas, porque, como você mesma sempre explicou, não tinha mais aquela questão do "inimigo único". Enfim, com a redemocratização, pulverizam-se as agendas, porque não tem mais o inimigo único que era o Estado autoritário. Então, obviamente, não haverá grandes manifestações massivas como tinha na década de 80 . Mas, por outro lado, como vocês mesmas reconhecem no livro Democracia, Sociedade Civil e 
Participação ${ }^{7}$, o trabalho do Gabriel Feltran teve o mérito de pensar o desafio da construção democrática num espaço completamente diferente do espaço participativo institucional.

ED: Com certeza! Mas Gabriel escreve já nos anos 2000. $\mathrm{O}$ que eu estava querendo apontar era que naquele contexto do final dos anos 1990 os chamados "movimentos disruptivos" tinham muito pouca visibilidade e, eu diria, tinham muito pouca importância. Todo mundo sabe que os movimentos sociais, com exceções - e o MST é uma delas - foram investir na participação institucionalizada. Então, o que eu estou tentando dizer é que não era um grande tema, porque não existia em dimensão significativa. Não dá para pensar o passado à luz do olhar de hoje.

Talvez outro exemplo dessas diferentes "ênfases" em diferentes temas, e pensando na contiguidade com a realidade, que mencionei no início, houve um determinado momento onde a ideia de "sociedade civil", com a sua pluralidade, com a sua dimensão, passou a ser politicamente mais visível e, portanto, mais importante, do que os movimentos sociais individualizados, digamos assim.

Eu não acho, ao contrário do Adrian Gurza Lavalle ${ }^{8}$, que a ideia da sociedade civil significou um abandono dos movimentos sociais. Talvez tenha significado uma inflexão para ampliar o foco, e essa ampliação estava se dando no real. Acho que a preocupação com o papel da sociedade, com a participação, permaneceu a mesma. Tem que se pensar no contexto. Eu reconheço com muita clareza que essa visibilidade do tema da sociedade civil tem a ver com a influência de contextos nacionais outros. Ou seja, houve, claro, como sempre tem, uma importação do que se fazia lá fora e, por outro lado, o fato de que a própria ideia da sociedade civil já estava começando a ser ressignificada. Portanto, essa visibilidade

7 DAGNINO, E.; TATAGIBA, L. (orgs.) Democracia, sociedade civil e participação. Chapecó: Argos, 2007.

${ }^{8}$ GURZA LAVALLE, A. Sem pena nem glória: o debate sobre a sociedade civil nos anos 1990. Novos Estudos, n. 66, p. 91-109, 2003. 
também tinha a ver com isso. Ou seja, em torno do conceito, da ideia de sociedade civil, havia interesses muito variados e era preciso entrar nessa disputa de significados.

E temos que voltar a falar do tamanho da tarefa da participação institucionalizada. Uma das coisas que a gente explicava no livro Sociedade civil e espaços públicos ${ }^{9}$, era o fato de que era muito complicado para os movimentos sociais enfrentarem as duas frentes - mobilizatória e institucional - de forma simultânea, que ambas precisavam ser complementares. Então, houve uma escolha por parte dos movimentos sociais, que o foco analítico foi lá acompanhar.

AC: Neste dossiê do fim dos anos 1990, o Grupo falava de experiências municipais importantes para refletir sobre como a sociedade poderia construir uma gestão democrática, muitas delas capitaneadas pelo PT. Qual seu balanço sobre o PT no governo federal, até que ponto é possível dizer que houve um aprofundamento da gestão pública democrática no governo federal? Ou não houve?

ED: No artigo com a Ana ${ }^{10}$, dizemos que o aprofundamento da gestão pública democrática no governo federal foi muito limitado. E mais limitado ainda no que tange à democracia participativa. Sim, houve um crescimento quantitativo. Houve uma coisa que eu acho importante e virtuosa, que também está no artigo, que é uma expansão da participação a áreas que ainda não estavam sendo contempladas. Agora, a dimensão da importância que a democracia participativa ocupava dentro do PT e, especialmente, dentro da corrente hegemônica do PT, era extremamente limitada. Será que não é possível pensar que houve uma confluência perversa entre, pelo menos, dois projetos que o

${ }^{9}$ DAGNINO, E. (org.) Sociedade civil e espaços públicos no Brasil. São Paulo: Paz e Terra, 2002.

${ }^{10}$ DAGNINO, E.; TEIXEIRA, A. C. C. The participation of civil society in Lula's Government. Journal of Politics in Latin America, v. 6, n. 3, p. 39-66, 2014. 
PT tinha? Sendo um o chamado "projeto de poder": "Queremos chegar lá e lá queremos permanecer". E esse é um projeto que tinha uma importância - todos sabemos - gigantesca. E o outro projeto era aquilo que levou o PT para lá: combater a pobreza e a desigualdade, em defesa da participação etc.

A confluência perversa dos dois projetos - de poder e do PT - aparece com muita clareza não só com relação à questão da participação, mas também em relação à política social, que era bífida, digamos assim. Ela tem dois lados, duas faces. E eu acho que cada uma dessas faces está atrelada a um dos projetos. Quer dizer, de um lado sim, ela tinha boas intenções: combater a pobreza, construir a igualdade. De outro lado, ela fornecia votos e solidificava essa figura do grande líder. E aí você tem o que você tem. Um jogo perverso, que faz a gente se perguntar, enfim, que alternativas havia...

AC: Mas por que toda experiência prévia no nível local não conseguiu ganhar nenhum tipo de tradução no nível nacional quando o PT chegou ao poder?

ED: É curiosa essa coisa dos ganhos da participação no governo Lula. Eu acho muito irônico que a visibilidade da chamada arquitetura participativa se revelou mínima na sociedade. Mínima! Quais são as evidências disso? O monumental desastre da proposta do Sistema Nacional de Participação Social ${ }^{11}$. Por quê? Porque as pessoas nem sabiam do que se tratava. Em 2013, nos protestos, o Lula reage aos protestos, com um artigo no New York Times, e nem menciona a "realmente existente" arquitetura participativa. O Lewandowski tem um artigo, no fim do ano passado, na Folha (coluna Tendências/Debates), que chama Democracia Participativa $J^{12}$. Ele fala como se fosse preciso inventá-la! Eu me pergunto: os

\footnotetext{
${ }^{11}$ O Decreto 8343/2014, que versava sobre a Política Nacional de Participação Social, foi rejeitado pelo Congresso Nacional.

12 LEWANDOWSKI. L. Democracia participava já. Folha de São Paulo, 4 de março/2017. Disponível em: < http://www1.folha.uol.com.br/ opiniao/2017/09/1915276-democracia-participativa-ja.shtml?loggedpaywall >. Acesso em: 10 de março de 2018.
} 
milhões que foram para a rua em 2013 teriam alguma noção de canais possíveis de participação? $\mathrm{Ou}$, se tinham, eventualmente - o que eu duvido muito - como eles avaliavam esses canais? Porque, evidentemente, o que 2013 mostra para mim, antes de qualquer coisa, é o ápice da crise de representação.

E o mais irônico de tudo é que essa crise de representação só se agrava. Eu acho que hoje, a gente tem que arranjar outra expressão para falar disso, porque "crise de representação" é muito trivial. E a alternativa disponível, que é ampliar essa representação, para atingir a sociedade, enfim, está totalmente derrotada e ignorada.

Me surpreendi com o Vladmir Safatle, que eu leio fielmente, mencionando há uns meses atrás a participação. Fora isso, nada, ou quase nada.

Com certeza, isso reflete o pouco empenho e o compromisso do PT como um partido no governo nessa questão. Não é? E, se você for ver, as forças efetivamente comprometidas com a participação e, a rigor, com a construção democrática, foram marginalizadas dentro do partido. Bons exemplos são o Tarso Genro e o Olívio Dutra, não casualmente os responsáveis pelas experiências de participação mais inovadoras e bem sucedidas em níveis locais.

AC: A sua visão dos anos 1990 de que haveria uma confluência perversa entre dois projetos-político, um neoliberal e outro democrático-participativo foi muito disseminada no Brasil. Foi uma ideia que forneceu uma chave de leitura que fez muito sentido para acadêmicos e militantes, pois apontava como, em torno da ideia da participação ativa da sociedade, havia um consenso só aparente. A impressão hoje parece ser que a ideia de uma sociedade participativa sumiu do mapa político. Você concorda? E se sim, como foi possível que isso tenha ocorrido? Há outros projetos hegemonizando o debate político?

ED: A ideia de confluência perversa tem sido muito utilizada. E eu fico me perguntando, como disse antes, se não houve uma confluência perversa entre o projeto de poder e o projeto original do PT. O que eu vejo é que algo que era constitutivo do projeto do PT que sempre foi a mobilização e a organização, e, portanto, a 
construção hegemônica na sociedade, foi para o espaço totalmente. Fico nostálgica da época em que se falava de "educação popular", formação política. A não ênfase nessa questão pelo PT foi um dos maiores pecados do PT. Eu estou falando daquilo que o Gabriel Feltran fala na tese de mestrado dele ${ }^{13}$, da tela do cinema.

AC: É. Talvez a única tela foi tematizar a pobreza. É uma tela que tem seus limites, mas para o tamanho da desigualdade brasileira, não é tão banal assim.

ED: Eu acho que você tem inteira razão ao lembrar isso. Eu fui excessivamente negativista. Mas não é à toa que a questão da pobreza acabou servindo ao projeto de poder. Então, não é à toa que ela é que tenha sido privilegiada. Além do que, houve uma apologia ao consumo (que era o que o "mercado" precisava, para vender mais carros, etc., etc.) que não foi acompanhada, como poderia ter sido, de um estímulo ao avanço dos direitos e da cidadania, ou à organização coletiva, participação, etc.

O trabalho de formiguinha que implica a mobilização dançou. Dançou. E aí eu não estou falando só do governo até porque o papel do governo talvez deva ser restrito a oferecer condições propícias. Mas é papel principalmente do partido, da esquerda em geral e dos movimentos sociais. E as consequências disso são o que a gente está vendo agora, esse vazio sendo ocupado pelo conservadorismo, especialmente o conservadorismo desinformado, para dizer o mínimo.

TT: Você sempre teve muitas ressalvas em relação ao termo "cooptação" quando ele era utilizado para analisar a inserção institucional dos movimentos sociais junto ao sistema político. Poderia falar um pouco melhor sobre isso? E após a experiência petista no governo federal, você ainda considera que o termo seja totalmente inadequado para analisar essas relações?

${ }^{13}$ FELTRAN, G. Desvelar a política na periferia: histórias de movimentos sociais em São Paulo. Tese (mestrado), Universidade Estadual de Campinas, Instituto de Filosofia e Ciências Humanas, Campinas, 2003. 
ED: Nunca disse que o termo seja totalmente inadequado para analisar essas relações. Meu primeiro problema com esse termo - cooptação - é que ele, em geral, é usado como se fosse autoexplicativo. Parece ser desnecessário explicar o que a constitui e, muito menos, analisar o conteúdo dessa relação. Nesse sentido, é um "conceito"(?) simplificador, superficial, que muito frequentemente se ampara nas aparências. $\mathrm{O}$ segundo problema é que parece haver um pressuposto nessa noção sobre os sujeitos que são objetos de cooptação. No caso, os movimentos sociais, que seriam, portanto, inocentes, inconscientes, massa de manobra, incapazes de agência, de fazerem as suas próprias escolhas políticas. Aliás, eu nunca ouvi falarem de cooptação em relação a políticos e partidos de direita. É sempre a esquerda que coopta, né? E, por último, eu acho que houve várias situações que poderiam ter sido analisadas de outra maneira, se o seu conteúdo e não a sua mera aparência tivessem sido investigados de fato. Aquilo que muitas vezes aparece como cooptação pode ser algo distinto: pode se tratar de alianças, compartilhamentos de um mesmo projeto, convergências entre sujeitos de estatutos diferentes. Quando os movimentos sociais nos governos Lula, por exemplo, diminuem a pressão sobre o governo porque acreditam que é mais importante, num determinado momento, assegurar a viabilidade desse governo porque isso faz mais sentido com os interesses do movimento a médio prazo, eles foram cooptados? Quando aceitam participar do governo assumindo cargos no aparato de estado, foram cooptados? Que há essa diferença empírica na relação de poder, com certeza. Que peso têm essas lógicas de poder? Tem um artigo que eu gosto muito da Wendy Wolford sobre o MST (apresentado num Congresso da LASA em Toronto, em 2004) em que a ideia central é que o MST cooptou o Estado. O Incra, no caso, que defendia as demandas do movimento. Para mim, a coisa mais ilustrativa dessa história toda sobre cooptação é a famosa citação da tese do Gustavo Cavalcanti ${ }^{14}$ sobre a relação do movimento

${ }^{14}$ CAVALCANTI, G. C. V. Uma concessão ao passado: trajetória da União dos Movimentos de Moradia de São Paulo. Tese (mestrado), Universidade de São 
de moradia com o governo Marta Suplicy (2001-2004), quando a militante do movimento diz:“(...) nós acabamos pecando talvez por não exigir mais da Marta, pressionando mais. E, por outro lado, pecando porque não conseguimos reeleger ela (...)". Foi um dilema para os movimentos sociais. Foi uma decisão correta? Com o que tinha se passado com os governos anteriores (Maluf e Pitta) acho que os movimentos tinham muita clareza sobre a importância da reeleição do PT, não?

Ou seja, há outras possibilidades de pensar essas relações muito além da questão mera e simples da cooptação. O que não significa que ela não tenha ocorrido enquanto subordinação, tutela, perda de autonomia. Tem que ter rigor teórico, mas também empírico. Tem que ver do que se trata.

Essa questão também rebate sobre a (ainda não resolvida) questão da autonomia dos movimentos sociais, que insistentemente ainda é pensada como ausência de relações entre eles e a sociedade política, o Estado, partidos, etc. Quando essas relações existem, sejam quais forem, são recorrentemente pensadas no registro da cooptação. Eu acho que uma chave não explorada nessa questão é pensar a autonomia em relação aos projetos que defendem e animam os respectivos movimentos sociais: o quanto as relações com o Estado contribuíram ou não para a sua implementação? Que recuos ou avanços essas relações trouxeram a esses projetos?

TT: Quando eu elaborei essa pergunta, estava pensando na questão do pacto lulista. Eu não sei se cooptação é o melhor termo, mas, você consegue enxergar que, em alguma medida, o pacto lulista (pensado nos termos do André Singer ${ }^{15}$ ) teve um impacto negativo nos movimentos sociais?

ED: É o que eu acabei de dizer: tem que ver caso a caso. Em termos gerais, a gente vivia se perguntando: “Dos males o

Paulo, Faculdade de Filosofia, Letras e Ciências Humanas, São Paulo, 2006, p.125.

${ }^{15}$ SINGER, A. Os sentidos do Lulismo: reforma gradual e pacto conservador. São Paulo: Companhia das Letras, 2012. 
menor? Valeu a pena?" Eu acho que essa questão se colocou, evidentemente, para os movimentos sociais também. E eles fizeram a sua avaliação. Certamente aqueles que esperavam transformações estruturais, rupturas substantivas, se frustraram. Agora, tem uma coisa estranha na argumentação do André Singer, que é "o povo brasileiro não gosta de bagunça". Então, também o lulismo funcionou, porque se fez as coisas sem bagunça, ou seja, sem rupturas. Eu não sei de onde ele tirou essa ideia. No limite, ela questiona a própria possibilidade de mobilização e organização política. Como é possível afirmar uma coisa dessas? Baseado em que pesquisa? Porque se é assim, aquilo que cobro que o PT não fez e que deveria ter feito, teria sido impossível, ou muito difícil.

TT: De qualquer forma, você acredita que o poder de mobilização dos movimentos populares foi afetado pela sua intensa inserção institucional junto ao Estado no período dos governos do PT? Alguns estudiosos alegam que isso (a perda da capacidade mobilizatória) foi uma consequência inevitável do pacto lulista. Como você enxerga esta questão?

ED: Têm várias dimensões. Não vamos simplificar. Eu acho que a figura do Lula, que hoje está sendo examinada de cima para baixo, de baixo para cima, com intenções as mais perversas, tem um peso aí. Não é, digamos, um simples candidato de esquerda que foi eleito. Do ponto de vista do povo, do ponto de vista dos movimentos sociais, eu acho que tem aí dimensões que impactam as pessoas, impactam os movimentos sociais. Acho que as promessas de futuro que o Lula encarnava tinham um impacto muito forte nas pessoas, forte o suficiente para que se fizesse uma aposta, colocando as fichas nessa figura e no seu governo, que abria janelas como nunca havia ocorrido antes. Agora, sem dúvida o poder de mobilização foi afetado pela legitimidade que o Lula tinha. E também pela inserção institucional dos movimentos. Por várias razões, a começar pelo fato de que não houve fôlego para manter as duas frentes de luta. A sedução da promessa de uma participação efetiva no poder decisório e as novas exigências que esse novo papel colocou foram muito fortes. E o PT, enquanto 
partido, abandonou de vez seu projeto de construção hegemônica na sociedade e se concentrou nas tarefas de ocupação do Estado.

AC: E tem um contexto de desmobilização que é para além da relação do PT com a sociedade brasileira. Se você pensa nos anos 80 , quando, com todos os problemas, havia uma perspectiva de estar empregado, e imaginar hoje, que é uma sociedade que já desistiu do trabalho... Qual é a capacidade de mobilização dessa sociedade? Se pensar no MST, qual é a alternativa no campo se o que domina é o agronegócio? Que discurso mobilizador conseguiria ser mais forte do que o agronegócio?

ED: Isso tem a ver com o movimento do capitalismo. Um bom gancho para chegar na história do capitalismo é pensar a dificuldade de mobilização e organização. Como mobilização tem sido impactada pelas modificações estruturais do capitalismo. Por exemplo, é absolutamente impressionante o mundo que essa nova lei trabalhista constrói. Como ela muda, transforma as condições. Aqui tem evidentemente, o compromisso e o empenho dos governos para enfrentar isso, que falhou. Mas tem também a correlação de forças. E aí eu lembrei do Jessé de Souza. No fundo, essa polêmica toda do seu último livro" , eu acho que é uma "não questão". Separar, isolar a herança da escravidão de outras coisas, que ele aponta, não faz o menor sentido. Por que separar? Mas de qualquer maneira, uma das coisas que ele afirma, é o tamanho dessa correlação de forças. Com o que a gente está lidando? É aí o que eu disse antes, que eu acho que, lá atrás, a gente subestimou o tamanho dos obstáculos. Mas, de novo, não fazia sentido dar peso ao obstáculo naquele momento.

AC: Pensando mais internacionalmente (não somente no Brasil), há experiências hoje que te chamam a atenção em termos de construção e aprofundamento da democracia? Quais e por quê?

\footnotetext{
${ }^{16}$ Souza, J. A elite do atraso: da escravidão à lava jato. Rio de Janeiro: Leya, 2017.
} 
ED: Tudo é muito confuso ainda. Para além do Jeremy Corbyn, o novo líder do Labour Party na Inglaterra, que está conseguindo mobilizar os jovens, eu poderia mencionar Barcelona. O que eu vi, com os meus olhos? Uma relação muito íntima e muito próxima entre movimentos sociais e sociedade política.

$\mathrm{Eu}$ assisti uma reunião em que três deputados, eleitos no parlamento espanhol, da Espanha, pela Catalunha, discutiram sobre os cem primeiros dias de mandato. Nos confins do inferno, lá vou eu. Cheguei lá e era em catalão, mas foi fascinante. Eu pensei: é capaz de ser uma coisa só celebratória e tal. Coisa nenhuma! Um auditório lotado de gente e uma quantidade de perguntas absolutamente sérias, algumas embaraçosas. Cobrança e um diálogo de ida e volta absolutamente fascinante. Então, é isso que me impressionou. Ou seja, eles estão efetivamente construindo um projeto compartilhado.

Então, como eu trago isso para cá? Isso eu acho que isso foi verdade durante parte da história do PT e eu acho que se acabou.

No caso do Corbyn, do Labour Party, eu também estive em um comício dele, e foi outra experiência fascinante. Porque comício inglês não tem nada a ver com o que a gente faz aqui! O Corbyn é um cara metido em um partido secular, protagonizado por aquilo que na França se chamava de elefantes do Partido Socialista, incapazes de se renovar e de ouvir vozes que não as suas. Mas ele tem uma base de juventude absolutamente impressionante e um diálogo muito próximo com ela. Não é tão impressionante quanto Barcelona, mas me impressiona o nível de proximidade que ele tem com a sua base, porque é disso que eu estou falando. Essa proximidade, essa capacidade de interinfluências, de compartilhamento.

TT: Desde 2013 pelo menos, vemos que novos atores (para recuperar os termos do Eder Sader) entraram em cena à direita e à esquerda: jovens feministas, ocupações secundaristas, MBL, apoiadores de Bolsonaro... Do seu ponto de vista, que nova cena é esta? Que novos atores são esses? 
ED: Sim, há novos atores e novas atrizes, felizmente! Com uma nova história, novos temas e novas formas de organização e mobilização. E não é fácil pensar esse novo cenário, especialmente porque ainda estamos presos a categorias antigas, talvez? Para não demonizar totalmente o governo petista, eu acho que houve avanços interessantes na questão racial e de gênero. Aí sim, houve uma tela, com um conteúdo nítido e mobilizador, claro que não isento de contradições. E eu acho que se vê claramente o quanto isso foi importante. O resultado está aí. Quer dizer, o que hoje se tem de positivo, no meio dessa desgraça fascista, são essas questões. Com certeza, mal ou bem, a questão racial e a questão do gênero, foram tocadas para frente o tempo todo nos governos petistas.

TT: Que tipo de luta estamos travando hoje e por que há tanta dificuldade em se construir resistências na sociedade?

ED: Eu ainda acho que estão faltando forças articulatórias. É um pouco repetir o óbvio, mas de novo, a tela. Para articular é preciso ter tela, oferecer um espelho, referências comuns nas quais as pessoas possam se enxergar, se identificar, sem que as suas próprias referências sejam recusadas, mas, ao contrário, se somem, ocupem o seu espaço nessa tela. Eu apostava muito na ideia dos direitos, da cidadania, como uma possibilidade de guarda-chuva articulatório, especialmente pela sua plasticidade e uma capacidade integradora das diferenças, e acho que isso funcionou durante algum tempo. Mas essa linguagem se esvaiu... As próximas eleições poderiam oferecer uma possibilidade de articulação, a emergência de um novo projeto. Mas tenho sérias dúvidas de que isso vá ocorrer e de que a gente vai ter algum tipo de debate real sobre questões de fundo. Agora, acho que os modelos de participação/representação existentes (e derrotados) têm que ser repensados. É desanimador pensar que aquilo que escrevíamos em 2002 sobre os limites e as dificuldades encontrados permanece até hoje, tal qual... A chamada "inclusão/participação digital", que tem aparecido com frequência como alternativa, me parece extremamente mitificada. Há estudos que apontam alguns 
desses mitos e limites: um projeto de pesquisa na Inglaterra que se chamou "Making all voices count" é uma referência interessante. ${ }^{17}$

AC: Ao escrever sobre os projetos políticos em disputa, você mencionava existirem outros projetos como o autoritário/ conservador. Seu trabalho também apontou para o autoritarismo social, contra os quais os movimentos sociais se insurgiam. Com o desenrolar do golpe contra Dilma e os subsequentes golpes contra os direitos sociais, ficou evidente que o autoritarismo social está firme e forte. Como entender o momento atual? É possível dizer que os movimentos estão perdendo a batalha para o autoritarismo? Em que ponto exatamente estamos na "construção democrática" brasileira?

ED: Primeiro, é evidente que a construção democrática está sofrendo um retrocesso gigantesco, com uma dimensão e um alcance avassaladores. Agora, o autoritarismo social baseado em critérios de raça, gênero, eu acho que foi encarado pelos governos petistas. Então, quando a gente avalia o governo do PT e tudo o que se passou nesse tempo, inclusive a lacuna da organização da formação política, eu acho que a gente tem que ter cuidado, porque houve áreas onde certamente houve avanço, que hoje querem destruir. Nesse sentido, o retrocesso e o novo ativismo da direita conservadora é, seguramente, uma reação a esses avanços. Incluído aí a reação à ampliação do consumo dos mais pobres. Compartilho o diagnóstico de que o "ódio de classe" é um componente central do antipetismo e da rejeição da esquerda. É claro que, se o PT não tivesse fornecido motivos para os argumentos mais legítimos, como a recusa da corrupção, esse ódio permaneceria menos visível e explícito do que é hoje. Nesse sentido, a ironia é que o avanço e a agressividade da direita nos dá a medida dos relativos avanços que tivemos...

${ }^{17} \mathrm{Um}$ exemplo é o texto de Herringshaw, V. Increasing citizen voice and government responsiveness: What does success really look like, and who decides? Making All Voices Count Programme Learning Report, Brighton: IDS, 2018. 
AC: Ainda sobre o PT no governo federal, em texto recente você escreveu que o neodesenvolvimentismo é um retorno a uma concepção de estado forte e autossuficiente e a uma centralização das práticas políticas que acabam por esvaziar as práticas de experimentação democráticas. De que formas este modelo neodesenvolvimentista afetou as experimentações democráticas?

ED: O neodesenvolvimentismo aparece como contraponto e combate ao neoliberalismo. É a ideia de que é preciso um Estado forte, interventor pró desenvolvimento. O problema é que, no bojo disso, a concepção de Estado não foi alterada. O novo desenvolvimentismo defende uma concepção velha de estado. É impressionante a coincidência de termos que o senhor Bresser Pereira e seus colegas utilizam com a concepção de Estado da origem do velho desenvolvimentismo, das décadas de 30 e 40 . Ou seja, o Estado novamente atuando como "o agente fundamental da transformação social", com exercício monopólico do poder decisório, dominado pelo saber tecnocrático e fundado numa democracia elitista. O que significa isso? Que a participação da sociedade, a "partilha do poder", todas as experiências democratizantes, toda a reflexão democratizante que ocorreu nesse país desde os anos 80, foram totalmente ignoradas. Ou seja, a reconfiguração do Estado, que até supostamente ocorreu ou deveria ter ocorrido, arquitetura participativa, etc., inexiste, silêncio total e completo sobre isso. Quando há referências à participação/representação, elas se limitam - acriticamente - à democracia representativa ou então às OSCIPS, como na reforma do estado de 1995 do Bresser. Então, realmente, o pecado maior do neodesenvolvimentismo é não ter pensado a reconfiguração do Estado no sentido do aprofundamento democrático, o que seria efetivamente "novo". Este "paradoxo" não é restrito ao Brasil; os governos de esquerda que se elegeram com um compromisso com a participação e com a construção democrática adotaram também o modelo neodesenvolvimentista. E vejam o que aconteceu no Equador, o que está acontecendo com o Evo. Não vou nem falar da Venezuela, com Chavez e Maduro. No caso brasileiro, o que é absolutamente desanimador e frustrante, é o fato de que houve, 
sim, construção. Não é como se não tivesse havido e nós, por este motivo, estivéssemos forçados a manter a mesma coisa. Houve experiências, houve inovações e isso não penetrou essa concepção neodesenvolvimentista. Não é à toa que, muito mais do que o Lula, a grande defensora disso foi a Dilma, para quem a participação, enquanto bela tecnocrata e como (supostamente) boa gestora, nunca teve a menor importância. Muito pelo contrário, eu acho que ela sabotou a ideia, veja-se o encaminhamento desastroso do decreto do Sistema Nacional de Participação.... Nada mais longe dos governos dela do que a "participação como método de governo", como pretendia esse decreto.

Evidentemente, não se trata de por em questão a ênfase no papel proativo do Estado para confrontar o predomínio neoliberal do mercado e suas várias implicações perversas. Mas qualquer proposta de reconfiguração do Estado que não incorpore e aprofunde a participação da sociedade no poder decisório só reforçará o retrocesso democrático. 
